\title{
Role of angiotensin II and vasopressin receptors within the supraoptic nucleus in water and sodium intake induced by the injection of angiotensin II into the medial septal area
}

V.R. Antunes, G.M.P.A. Camargo, R. Saad, W.A. Saad, A.C. Luiz and L.A.A. Camargo

\author{
Departamento de Fisiologia e Patologia, Faculdade de O dontologia, \\ Universidade Estadual Paulista, Araraquara, SP, Brasil
}

\section{Correspondence \\ L.A.A. Camargo \\ Departamento de Fisiologia e \\ Patologia \\ Faculdade de O dontologia, UNESP \\ Rua Humaitá, 1680 \\ 14801-903 Araraquara, SP \\ Brasil \\ Fax: +55-16-222-4823 \\ E-mail: silvana@ foar.unesp.br.}

Research supported by FAPESP (No. 95/3059-6) and CN Pq (No. 521467/95-0).

Received April 10, 1997 Accepted August 18, 1998

\section{Abstract}

In this study we investigated the effects of the injection into the supraoptic nucleus (SON) of non-peptide AT1- and AT2-angiotensin II (ANG II) receptor antagonists, DuP753 and PD123319, as well as of the arginine-vasopressin (AVP) receptor antagonist $\mathrm{d}\left(\mathrm{CH}_{2}\right)_{5}-\mathrm{Tyr}(\mathrm{Me})$ $\mathrm{AVP}$, on water and $3 \% \mathrm{NaCl}$ intake induced by the injection of ANG II into the medial septal area (MSA). The effects on water or $3 \% \mathrm{NaCl}$ intake were assessed in 30-h water-deprived or in 20 -h water-deprived furosemide-treated adult male rats, respectively. The drugs were injected in 0.5 $\mu \mathrm{l}$ over 30-60 s. Controls were injected with a similar volume of $0.15 \mathrm{M} \mathrm{NaCl}$. Antagonists were injected at doses of 20, 80 and $180 \mathrm{nmol}$. Water and sodium intake was measured over a 2-h period. Previous administration of the AT1 receptor antagonist DuP753 into the SON decreased water $(65 \%, \mathrm{~N}=10, \mathrm{P}<0.01)$ and sodium intake $(81 \%, \mathrm{~N}=8, \mathrm{P}<0.01)$ induced by the injection of ANG II (10 nmol) into the MSA. Neither of these responses was significantly changed by injection of the AT2-receptor antagonist PD123319 into the SON. On the other hand, while there was a decrease in water intake $(45 \%, \mathrm{~N}=9, \mathrm{P}<0.01)$, ANG II-induced sodium intake was significantly increased $(70 \%, \mathrm{~N}=8, \mathrm{P}<0.01)$ following injection of the V1-type vasopressin antagonist $\mathrm{d}\left(\mathrm{CH}_{2}\right)_{5}-\mathrm{Tyr}(\mathrm{Me})$-AVP into the SON. These results suggest that both $\mathrm{AT} 1$ and $\mathrm{V} 1$ receptors within the SON may be involved in water and sodium intake induced by the activation of ANG II receptors within the MSA. Furthermore, they do not support the involvement of MSA AT2 receptors in the mediation of these responses.

\section{Key words}

- Angiotensin II

- AT1 receptors

- AT2 receptors

- $\mathrm{V} 1$ receptors

- W ater intake

- Sodium intake

- Medial septal area

- Supraoptic nucleus

- Rats 
Central injection of angiotensin II (ANG II) elicits prompt and pronounced responses such as increased blood pressure, thirst, sodium appetite, and the release of vasopressin (1). Electrical stimulation of the basal forebrain causes the release of arginine-vasopressin (AVP) and a prolonged thirst (2). Furthermore, exogenous application of ANG II increases the firing rate of the magnocellular neurosecretory neurons of the supraoptic nucleus (SON). This effect seems to be produced by the activation of functional ANG II receptors within the SON since it is revers-

Figure 1 - A, Photomicrograph of a hematoxylin-stained transverse section of the rat brain showing the site of injection into the MSA. B, Schematic representation of the location of the injection sites in the SON region (black areas). The numbers in the upper right part of each section indicate the rostrocaudal distance of that section from the bregma. LH, Lateral hypothalamic area; OX, optic chiasm; OPT, optic tract; SO, supraoptic nucleus; SOR, retro-chiasmatic supraoptic nucleus.

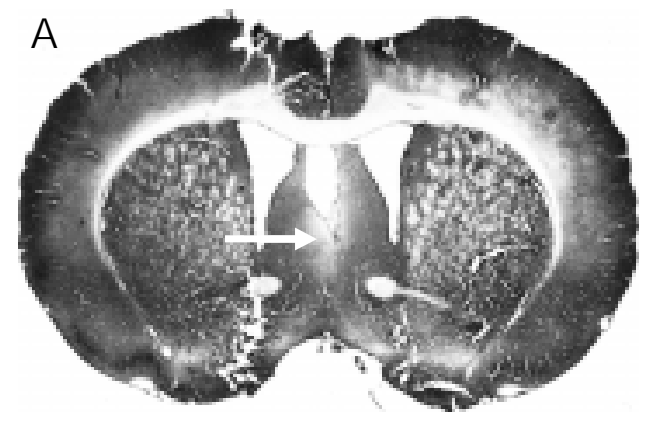

B

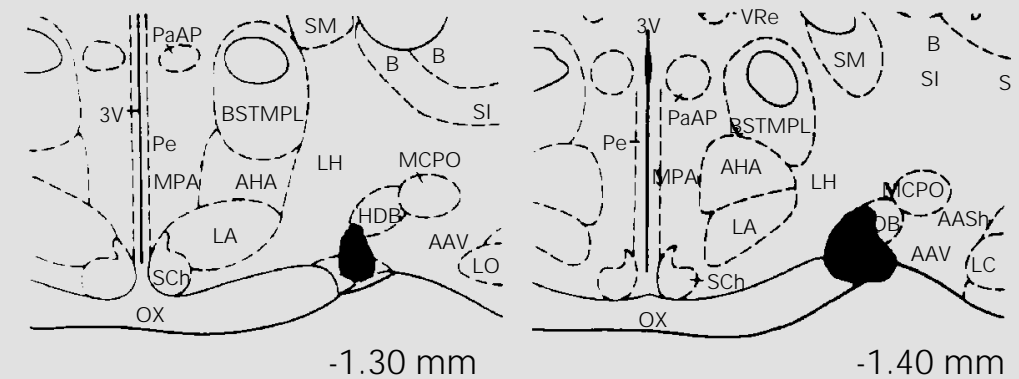

$-1.30 \mathrm{~mm}$

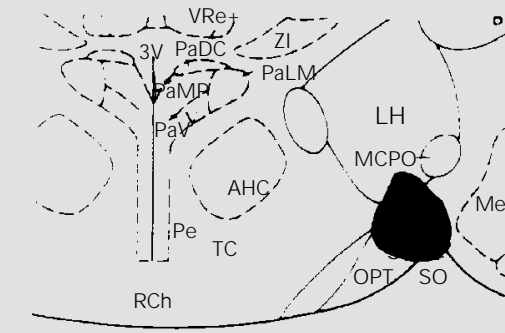

$-1.80 \mathrm{~mm}$

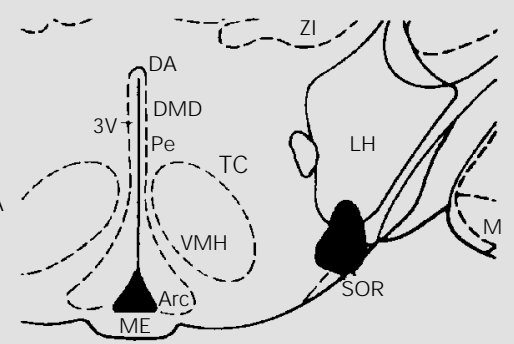

$-2.56 \mathrm{~mm}$ ibly blocked by the angiotensin peptide antagonist salarasin $(3,4)$. Application of the nonpeptide type 1 angiotensin antagonist DuP753 blocks the ANG II-induced depolarization in the SON. In contrast, application of the type 2 antagonist PD123177 was ineffective in blocking this response (5). Neurons of the septal nuclei are also sensitive to angiotensin (6). Since the septum is known to send efferents to the SON (7), we investigated whether the dipsogenic and natriorhexigenic effects induced by the injection of ANG II into the medial septal area (MSA) could be mediated by angiotensin and vasopressin receptors within the SON.

Male Holtzman rats weighing 250-300 g were anesthetized with tribromoethanol (20 $\mathrm{mg} / 100 \mathrm{~g}$ body weight, ip) and implanted with 10- and 12-mm long and 0.7-mm OD stainless steel cannulas into the MSA and SON, according to the coordinates of the Paxinos and Watson rat brain atlas (8). The cannulas were fixed to the skull with the aid of jeweler screws and dental acrylic resin and protected with a stiletto. Since water and sodium deprivation increases CNS synthesis of ANG II, further increasing water and sodium intake (9), water and $3 \% \mathrm{NaCl}$ solution were removed 30 and $20 \mathrm{~h}$ before the intracranial injections, respectively. Sodium depletion was further accomplished by the administration of a single dose of furosemide $(10 \mathrm{mg}, s c)$ to sodium-deprived rats. Moreover, at the time of ANG II injection food pellets were replaced with sodium-deficient ones, and the rat's cage was washed thoroughly to remove enviromental sodium residues. On the subsequent day $(20 \mathrm{~h}$ after furosemide injection) food was removed and $3 \% \mathrm{NaCl}$ was restored to the rats. ANG II ( 10 $\mathrm{nmol}$ ) or $0.5 \mathrm{ml}$ vehicle was injected into the MSA $20 \mathrm{~min}$ before $3 \% \mathrm{NaCl}$ was offered.

The screening test consisted of an injection of ANG II $(10 \mathrm{nmol} / 0.5 \mu \mathrm{l})$ into the MSA followed by the measurement of water intake over $30 \mathrm{~min}$. Each antagonist was also injected alone into the MSA at the dose of 
$180 \mathrm{nmol} / 0.5 \mu \mathrm{l}, 20 \mathrm{~min}$ before water or $3 \%$ $\mathrm{NaCl}$ was offered. Water or sodium intake was recorded over a 2 -h period using individual metabolic cages. The antagonists were injected into the SON 15 min before ANG II was injected into the MSA. ANG II (Sigma Chemical Co., St. Louis, MO), PD123319 and DuP753 (DuPont, Merck, Wilmington, $\mathrm{DE})$ and $\mathrm{d}\left(\mathrm{CH}_{2}\right)_{5}$-Tyr(Me)-AVP (Bachem, Bubendorf, Switzerland) antagonists were injected at doses of 20,80 and $180 \mathrm{nmol} / 0.5$ $\mu 1$.

At the end of the experiments, the rats were anesthetized with ether and perfused through the heart with saline followed by $10 \%$ formalin. The brains were then removed, stored in $10 \%$ formalin for 1 week and cut into $20-30-\mu \mathrm{m}$ coronal sections, which were stained with hematoxylin-eosin for light microscopy to determine the position of the cannula inside the MSA and SON (Figure 1). Data from rats for which the injection sites were visibly outside the target nuclei were excluded from analysis. Results are reported as means \pm SEM. Data were subjected to two-way ANOVA $v s$ doses, followed by the Newman-Keuls post-hoc test.

The injection sites are shown in Figure 1. Water and $3 \% \mathrm{NaCl}$ intake following the injection of ANG II into the MSA of controls and rats injected with antagonists are shown in Figure 2. Rats injected with ANG II into the MSA showed a significant increase in water and sodium intake compared with the $0.15 \mathrm{M} \mathrm{NaCl}$-injected group. DuP753 injected into the SON decreased (two-way ANOVA) water and sodium intake induced by ANG II injection in a dose-dependent manner. In contrast, injection of the vasopressin $\mathrm{V} 1$ receptor antagonist, $\mathrm{d}\left(\mathrm{CH}_{2}\right)_{5^{-}}$ $\operatorname{Tyr}(\mathrm{Me})-A V P$, into the SON caused a significant decrease in water intake and increased (two-way ANOVA) the sodium intake induced by ANG II injection into the MSA. Injection of PD123319 produced no effect on water or saline ingestion. The injection of DuP753, PD123319, and d $\left(\mathrm{CH}_{2}\right)_{5^{-}}$
Tyr(Me)-AVP alone (180 nmol) into the SON did not alter water $(11.5 \pm 0.9,10.3 \pm 0.7$, and $10.2 \pm 0.8 \mathrm{ml} / 2 \mathrm{~h}$, respectively) or $3 \%$ $\mathrm{NaCl}(6.4 \pm 0.9,4.9 \pm 0.8$, and $7.3 \pm 1.6 \mathrm{ml} /$ $2 \mathrm{~h}$, respectively) intake by water-deprived or sodium-depleted rats, respectively.

The present results show that whereas injection of the selective AT1 antagonist DuP753 into the SON reduced water and sodium intake induced by angiotensinergic activation of the MSA, the injection of PD123319, a selective antagonist for AT2 receptors, had no effect on these responses. In addition, they also show that the previous injection of $\mathrm{d}\left(\mathrm{CH}_{2}\right)_{5}-\mathrm{Tyr}(\mathrm{Me})-\mathrm{AVP}$, a V1
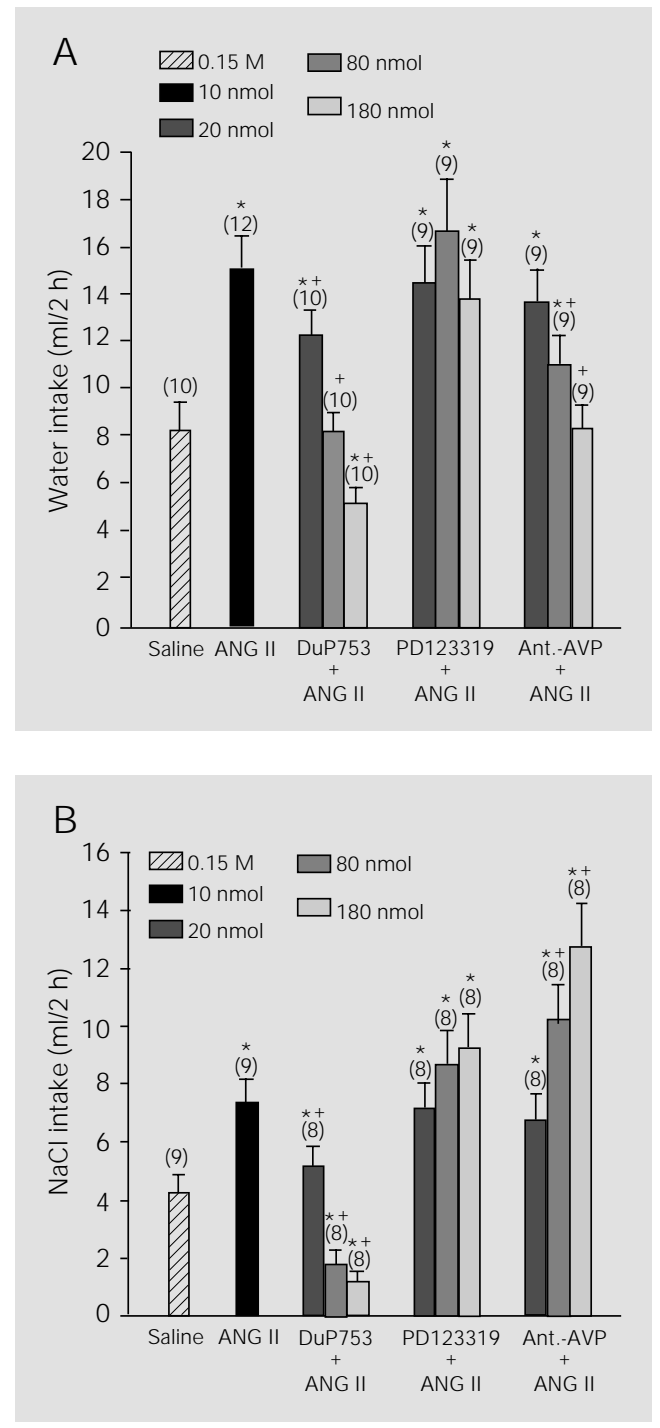

Figure 2 - Effect of pretreatment with DuP753, PD123319, $\mathrm{d}\left(\mathrm{CH}_{2}\right)_{5}$-Tyr(Me)-AVP (Ant.-AVP) or vehicle (saline) into the SON on water (A) and sodium (B) intake evoked by injection of ANG II into the MSA. Data are reported as mean \pm SEM. $* P<0.05$ compared to the saline group; $+P<0.05$ compared to the ANG II group (Neuman-Keuls post-hoc test). 
receptor antagonist, into the $\mathrm{SON}$ inhibited ANG II-induced water intake and increased the sodium intake.

Quantitative autoradiography with selective ANG II-receptor antagonists revealed that the SON of the rat contains AT1 receptors (10). Furthermore, it has been reported that water and salt appetite can be triggered by iontophoretically applied ANG II into the anteromedian septum (11). The vasopressin V1 receptor is also found in the MSA $(12,13)$, and treatment with the $\mathrm{V} 1$ receptor antagonist caused a marked decrease in receptor affinity for AVP (14). An endogenous origin for ANG II is suggested by various reports of angiotensin-like immunoreactivity in the magnocellular neurons of the SON (15). It is thus possible that ANG II is released locally from axon collaterals or somato-dendritic sites in a manner similar to that proposed for oxytocin or vasopressin (16). The septal in- fluence on the control of AVP and ANG II secretion is presumably mediated by cells projecting from this area to the vasopressincontaining magnocellular neurons of the SON (17).

In summary, the present results suggest that, whereas the AT1 receptors of the SON mediate water and $\mathrm{NaCl}$ ingestion induced by angiotensinergic activation of the MSA, the $\mathrm{V} 1$ receptors activate water intake but inhibit sodium ingestion.

\section{Acknowledgments}

The authors greatly appreciate the technical assistance of Aparecida C. Luiz, Reginaldo C. Queiróz, Silas P. Barbosa, and Silvia Fóglia. They also thank Silvana A.D. Malavolta for preparation of the manuscript, and Ana V. Oliveira and Fernando L. Capelli for animal care.

\section{References}

1. Reid J A (1988). Actions of angiotensin II on the brain: mechanisms and physiological role. American J ournal of Physiology, 246: F533-F543.

2. Szczpanska-Sadowska E, Sobocineska J \& Sadowski B (1982). Central dipsogenic effect of vasopressin. American J ournal of Physiology, 242: R372-R379.

3. J hamandas J H, Lind RW \& Renaud LP (1989). Angiotensin II may mediate excitatory neurotransmission from the subfornical organ to the hypothalamic supraoptic nucleus: an anatomical and electrophysiological study in the rat. Brain Research, 487: 52-61.

4. Okuya S, Inenaga K, Kaneko $T \&$ Yamashita H (1987). Angiotensin II sensitive neurons in the supraoptic nucleus, subfornical organ and anteroventral third ventricle of rats in vitro. Brain Research, 402: 58-67.

5. Yang CR, Phillips MI \& Renaud LP (1992). Angiotensin II receptor activation depolarizes rat supraoptic neurons in vitro. American J oumal of Physiology, 263: R1333R1338.

6. Simonnet $G$, Bioulac B, Rodriguez $F$ \& Vincent J D (1980). Evidence of a direct action of angiotensin II on neurones in the septum and in the medial preoptic area. Pharmacology, Biochemistry and Behavior, 13: 359-363.

7. Poulain DA, Lebrun CJ \& VincentJ (1981). Electrophysiological evidence for connections between septal neurons and the supraoptic nucleus of the hypothalamus of rat. Experimental Brain Research, 42: 260268.

8. Paxinos G \& Watson C (1986). The Rat Brain in Stereotaxic Coordinates. Academic Press, San Diego.

9. Thunhorst RT \& J ohnson AK (1994). Renin-angiotensin, arterial pressure, and salt appetite in rats. American J ournal of Physiology, 266: R458-R465.

10. Tsutsumi K \& Saavedra J M (1991). Characterization and development of angiotensin II receptor subtypes (AT1 and AT2) in rat brain. American J ournal of Physiology, 261: R209-R216.

11. Mousseau MC, Thornton SN, Martial FP, Lienard F \& Nicolaids S (1996). Neuronal responses to iontophoretically applied angiotensin II, losartan and aldosterone, as well as gustatory stimuli, in non-anesthetized control and desoxycorticosterone acetate-pretreated rats. Regulatory Peptides, 66: 51-54.
12. Dorsa DM, Brot MD, Shewey LNM, Myers KM, Szot P \& Miller MA (1988). Interaction of a vasopressin antagonist with vasopressin receptors in the septum of the rat brain. Synapse, 2: 205-211.

13. Poulain P, Lederis K \& Pittman OJ (1988). Subcellular localization and characterization of vasopressin binding sites in the ventral septal area, lateral septum and hypocampus of the rat brain. J ournal of Neurochemistry, 50: 889-898.

14. Swank MW \& Dorsa DM (1991). Chronic treatment with vasopressin analogues alters affinity of vasopressin in the septum and amygdala of the rat brain. Brain Research, 544: 342-344.

15. Renaud LP \& Bourque CW (1991). Neurophysiology and neuropharmacology of hypothalamic magnocellular neurons secreting vasopressin and oxytocin. Progress in Neurobiology, 36: 131-169.

16. Richard $P$, Moos $F$ \& Freund-Mercier $M J$ (1991). Central effects of oxytocin. Physiological Reviews, 71: 331-370.

17. Ferguson AV, Bourque CW \& Renaud LP (1985). Subfornical organ and supraoptic nucleus connections. American J ournal of Physiology, 249: R214-R218. 